\title{
Stan słuchu fonematycznego u pacjenta z implantem pniowym - studium przypadku
}

\section{Phonemic hearing in a patient with the auditory brainstem implant $(\mathrm{ABI})$ - a case study}

\author{
Magdalena Maszewska, Artur Lorens, Anna Piotrowska, Henryk Skarżyński \\ Instytut Fizjologii i Patologii Słuchu, Światowe Centrum Słuchu, Zakład Implantów i Percepcji Słuchowej, \\ Warszawa/Kajetany
}

Adres autora: Magdalena Maszewska, Światowe Centrum Słuchu, Zakład Implantów i Percepcji Słuchowej, ul. Mokra 17, Kajetany, 05-830 Nadarzyn, e-mail: m.maszewska@ifps.org.pl

\section{Streszczenie}

\begin{abstract}
Wstęp: Implant pniowy (ABI) to obecnie jedyna proteza słuchu dla osób z uszkodzeniem nerwów słuchowych. Wszczepiany jest on głównie pacjentom ze zdiagnozowaną neurofibromatozą typu 2 (NF2), w przebiegu której na nerwie słuchowym tworzą się guzy, co nieuchronnie prowadzi do całkowitej głuchoty. Pacjenci korzystający z systemu implantu pniowego uzyskują w badaniach niski poziom rozumienia dźwięków mowy. Jednym z czynników składających się na prawidłowy przebieg tego procesu jest słuch fonematyczny. Jest to umiejętność odbioru przez układ słuchowy cech dystynktywnych fonemów w danym języku, co pozwala na różnicowanie dźwięków mowy. Zaburzenia słuchu fonematycznego są przyczyną problemów z rozumieniem mowy i uniemożliwiają sprawną komunikację.
\end{abstract}

Cel: Celem pracy jest ocena stanu słuchu fonematycznego u pacjenta $\mathrm{z}$ dwoma implantami pniowymi, w tym ocena możliwości dyskryminacji głosek opozycyjnych, co jest jednym z warunków umożliwiających prawidłowy odbiór mowy.

Materiał i metody: Oceny stanu słuchu fonematycznego dokonano u użytkownika dwóch implantów pniowych. Do badania wykorzystano „Test do badania słuchu fonematycznego” autorstwa E. Szeląg i A. Szymaszek. Test przeprowadzono w warunkach ciszy.

Wyniki i wnioski: Stymulacja elektryczna realizowana przez dwa systemy implantu pniowego pozwala pacjentowi - w sprzyjających akustycznie warunkach - na odbiór i różnicowanie opozycyjnych głosek oraz paronimów bez posiłkowania się kontekstem wypowiedzi. Zatem stosowanie słuchowych implantów pniowych może być skuteczną metodą kompensacji utraconego, w przebiegu NF2, słuchu. W celu uogólnienia wniosków z badania wskazane byłoby przeprowadzanie podobnych badań u innych użytkowników implantów pniowych. Pomocne dla dalszego rozwoju programu rehabilitacji i wspomagania pacjentów w uzyskiwaniu jak największych korzyści z implantu pniowego byłoby przeprowadzenie badań dotyczących wpływu treningu słuchowego na rozwój kompetencji słuchowych dotyczących rozumienia mowy u pacjentów z ABI. Przeprowadzenie testu słuchu fonematycznego przed treningiem słuchowym i po takim treningu umożliwiłoby ocenę skuteczności podjętej interwencji.

Słowa kluczowe: implant pniowy $\bullet$ niedosłuch $\bullet$ słuch fonematyczny $\bullet$ głoska $\bullet$ neurofibromatoza typu 2

\section{Abstract}

Background: The auditory brainstem implant (ABI) is at present the only prosthesis of hearing available for people with damaged acoustic nerves. It is implanted most commonly in patients with diagnosed neurofibromatosis type 2 (NF2), which causes formation of tumours on the auditory nerve unavoidably leading to total deafness. ABI patients show in tests low speech understanding levels. One of the factors resulting in the correct course of this process is phonemic hearing, which is the ability of the auditory road to receive and differentiate diacritic features of phones and speech discrimination. Its dysfunctions lead to the problems with speech understanding and prohibit efficient communication.

Aim: To verify the phonemic hearing of a patient with two auditory brainstem implants, which will enable the assessment of patient's ability to discriminate opposing phones, which is one of the conditions for the proper reception of speech. 
Material and methods: The study involved an examination of a user of two ABIs using „Test do badania słuchu fonematycznego” („Phonemic hearing test” by E. Szeląg and A. Szymaszek). The test was conducted in silence.

Results and conclusion: The ABI enables its user - in favourable acoustic conditions - to receive and differentiate the opposing phones and paronyms without the aid of the sentence context. Thus ABI is an effective method of compensating for the hearing loss. It would be recommended to conduct such examinations in other ABI users, which could allow comparing the results. For the future development of the rehabilitation program and assisting patients to obtain the maximum benefits from the $\mathrm{ABI}$ it would be helpful to conduct studies of the effects of the auditory training for speech discrimination ability in the $\mathrm{ABI}$ patients. For that purpose it would be worthwhile to conduct phonemic hearing tests on the same group of patients twice: before and after the training, and to compare the results.

Key words: implant $\bullet$ hearing $\bullet$ phonemic hearing $\bullet$ phone $\bullet$ neurofibromatosis type 2

\section{Wstęp}

Słuchowe implanty pniowe (ang. Auditory Braistem Implant, $\mathrm{ABI}$ ) pozwalają słyszeć osobom, które nie mają nerwu słuchowego lub jest on nieodwracalnie uszkodzony.

Zasada działania systemu implantu pniowego polega na odpowiedniej stymulacji elektrycznej jąder brzusznych i grzbietowych nerwu ślimakowego usytuowanych w pniu mózgu [1]. W ten sposób możliwe jest ominięcie uszkodzonego nerwu słuchowego, a dla potrzeb odbioru dźwięku wykorzystywany jest dalszy, funkcjonujący odcinek drogi słuchowej. Nowoczesny system implantu pniowego złożony jest z części wewnętrznej - implantu, składającego się z odbiornika i stymulatora elektrycznego we wspólnej obudowie wraz z matrycą elektrod (płytką, na której umieszczone są kontakty elektrod), oraz z części zewnętrznej - cyfrowego, wielokanałowego procesora mowy. Część wewnętrzna jest wszczepiana operacyjnie: kapsuła implantu umieszczana jest w niszy w kości skroniowej i przykrywana płatem skórnym, a matryca elektrod wprowadzana jest w okolice jąder ślimakowych w pniu mózgu.

Do chwili obecnej głównym wskazaniem klinicznym do wszczepienia implantu pniowego jest utrata słuchu w przebiegu neurofibromatozy typu 2 (NF2). NF2 jest zespołem chorobowym, u podłoża którego leżą mutacje genetyczne. NF2 charakteryzuje się występowaniem guzów nerwu przedsionkowo-słuchowego oraz innych mnogich guzów w obrębie układu nerwowego. Wszczepienie implantu pniowego odbywa się najczęściej jednoczasowo $\mathrm{z}$ chirurgicznym usunięciem zmian w okolicy kąta mostowo-móżdżkowego [2].

\section{Słuch fonematyczny}

$\mathrm{W}$ literaturze można spotkać się z różnymi terminami dotyczącymi zagadnienia słuchu fonematycznego: obok pojęcia 'słuch fonematyczny', istnieją również określenia takie jak: 'słuch fonologiczny', 'słuch fonemowy' czy 'słuch fonetyczny'. Mimo czasu, jaki upłynął od momentu wprowadzenia tych pojęć do terminologii polskiej, między specjalistami i badaczami nadal nie ma zgodności co do zakresu znaczeniowego poszczególnych definicji.

Józef Kania jako definicję słuchu fonematycznego podaje: „umiejętność percypowania (wyodrębniania oraz identyfikowania) elementów fonologicznie relewantnych (istotnych), pomijania zaś cech dla procesu porozumiewania się redundantnych (nieistotnych)" [3].
Irena Styczek [4] natomiast określa słuch fonematyczny jako „umiejętność rozróżniania najmniejszych elementów składowych wyrazów, czyli fonemów. Jest to także umiejętność utożsamiania różnych wymówień głoski”.

W ujęciu Bronisława Rocławskiego [5] słuch fonemowy „jest to zdolność do kwalifikowania wyróżnionych z potoku mowy głosek jako przynależnych do określonych, fonologicznie zdeterminowanych klas głosek".

Agnieszka Domagała i Urszula Mirecka [6] za najszersze znaczeniowo uznały pojęcie 'słuchu mownego', na który składają się: zdolności warunkujące opanowanie systemu fonologicznego - czyli słuch fonemowy i fonologiczny słuch prozodyczny - oraz zdolności stanowiące o odbiorze funkcji pozasystemowych - czyli fonetyczny słuch segmentalny i fonetyczny słuch prozodyczny. Słuch fonemowy i fonologiczny słuch prozodyczny odpowiadają za kształtowanie się systemu fonologicznego w umyśle oraz jego późniejsze funkcjonowanie w komunikacji językowej.

Elżbieta Szeląg i Aneta Szymaszek [7] stwierdziły, że słuch fonematyczny „zabezpiecza wyodrębnianie z potoku dźwięków mowy tych cech, które odgrywają szczególne znaczenie dla identyfikacji danego fonemu, dzięki czemu dany wyraz można odróżnić od innych, o odmiennym znaczeniu".

Ze względu na różnorodność definicji oraz używanych w niej terminów należy zdefiniować pojęcia 'głoski' i 'fonemu'.

Zgodnie z definicją zaprezentowaną w „Encyklopedii wiedzy o języku polskim” Urbańczyka [8], „fonem to najmniejszy, dający się liniowo wydzielić, funkcjonalny segment formy językowej”. Głoska z kolei to elementarny, najmniejszy i pozbawiony znaczenia składnik potoku mowy - jest to fizyczna realizacja fonemu. Różnica między tymi pojęciami opiera się na funkcjonalności: fonem jest abstrakcyjną jednostką systemu językowego, zaś głoska jest realnie istniejącym dźwiękiem [7].

Wobec powyższych definicji, omawiając słuch fonematyczny, należy uwzględnić jego dwie funkcje: różnicowanie dźwięków mowy, czyli głosek, oraz zdolność do ich analizy i syntezy. Wykształcenie się tych zdolności jest warunkiem umożliwiającym prawidłowe rozpoznawanie wyrazów, a przez to także pośrednio prowadzenie efektywnej komunikacji i, w późniejszym czasie, nabywanie zdolności pisania i czytania. 
Kształtowanie się słuchu fonematycznego nie jest cechą wrodzoną i nie następuje samoistnie [7]. Jest ściśle związane $\mathrm{z}$ rozwojem osobniczym dziecka oraz $\mathrm{z}$ poziomem oddziaływań systemu fonologicznego danego języka. R. J. Lewina [3], obserwując dzieci, wyszczególniła pięć etapów kształtowania się słuchu fonematycznego, które są jednocześnie etapami rozwoju mowy u dzieci. Pierwszy etap to przedfonetyczne stadium rozwoju mowy: na tym etapie u dziecka w ogóle nie występuje różnicowanie dźwięków, brak też rozumienia mowy czynnej. Drugi etap to początki różnicowania głosek najmniej podobnych wymowa dziecka jest jednak niepoprawna i zniekształcona, a samo dziecko nie rozróżnia wymowy poprawnej od niepoprawnej u osób z otoczenia. Trzeci etap to czas, kiedy dziecko zaczyna różnicować głoski, umie też odróżnić wymowę poprawną od niepoprawnej. Na czwartym etapie dzieci, już z nielicznymi pomyłkami, potrafią różnicować wszystkie głoski, a ich wymowa jest zazwyczaj prawidłowa. Etap piąty to zakończenie rozwoju słuchu fonemowego, które zwieńczone jest poprawnym różnicowaniem wszystkich głosek przez dziecko oraz ich poprawną wymową.

Styczek twierdzi [4], że słuch fonematyczny zaczyna się rozwijać już w końcowym okresie gaworzenia, czyli między 9 a 12 miesiącem życia, zaś między 1 a 2 rokiem życia przypada jego najintensywniejszy rozwój. Rocławski natomiast, pracując nad tym zagadnieniem, przeprowadził badania [5], które wykazały, że drugi rok życia dziecka jest okresem intensywnego opanowywania systemu fonologicznego języka. Oznacza to, że zalążki słuchu fonematycznego pojawiają się około 7-9 miesiąca życia, a około 13-15 miesiąca dzieci odróżniają już znaczną liczbę głosek.

Prawidłowo wykształcony słuch fonematyczny warunkuje poprawne postrzeganie oraz produkcję dźwięków mowy. Jego zaburzenia powodują brak stabilności wzorców słuchowych głosek, przez co utrudniają rozumienie mowy i są przyczyną wadliwej realizacji tychże głosek. Później skutkuje to problemami z pisaniem i czytaniem. Mimo tak poważnych konsekwencji zaburzeń tej umiejętności nie powstała jeszcze ścisła klasyfikacja zaburzeń słuchu fonematycznego. Styczek [4] posługuje się podziałem ze względu na stopień deficytu zależny od:

- liczby opozycji nierozróżnianych;

- typu opozycji nierozróżnianych;

- liczby nierozróżnianych członów danej opozycji.

Stopień deficytu określany może być jako mały lub duży.

Osoby z deficytem słuchu fonematycznego mają trudności z rozróżnianiem pewnych opozycji lub ich członów, przeważnie dotyczy to głosek dźwięcznych i bezdźwięcznych. W przypadku dużej liczby problemowych głosek jedną z przyczyn może być wykształcenie się mowy bezdźwięcznej. Jest to zjawisko objawiające się zaburzeniami w wymowie dźwięczności, czyli zastępowaniu ich bezdźwięcznymi odpowiednikami. Duży stopień deficytu słuchu fonematycznego znacznie utrudnia i opóźnia rozwój mowy u dziecka - odpowiedzialny za to jest brak możliwości odbioru prawidłowych wzorców. Związane są z nim dwa zaburzenia: alalia percepcyjna, będąca wynikiem całkowitego braku rozwoju słuchu fonematycznego, oraz afazja akustyczna, spowodowana całkowitą utratą słuchu fonematycznego. Schorzenia te skutkują ograniczeniem rozumienia mowy [5].

Kurkowski [9] dysfunkcje wynikające z zaburzeń słuchu mownego przyporządkował jego składowym. Zaburzenia słuchu fonemowego będą objawiać się substytucjami głosek, a zaburzenia słuchu fonematycznego ich deformacjami. W efekcie prowadzić to będzie do mowy niezrozumiałej dla otoczenia. Problemy ze słuchem prozodycznym wpłyną na płynność wypowiedzi, natomiast dysfunkcja analizy i syntezy głoskowej będzie skutkowała trudnościami w czytaniu i pisaniu.

W celu uzupełnienia deficytów słuchu fonematycznego można stosować różnego rodzaju ćwiczenia mające na celu rozwijanie zdolności różnicowania głosek opozycyjnych. Mogą mieć one charakter słuchowo-gestowy, czyli np. klaskanie, wskazywanie palcem, lub słuchowo-werbalny, np. powtarzanie głoski za terapeutą.

Pierwsze narzędzie pozwalające na zbadanie poziomu deficytu słuchu fonematycznego opracowała Styczek [4]. Procedura badania składa się z trzech prób: literowej, sylabowej i wyrazowej. Test został stworzony do badania dzieci.

Test pozwalający na ocenę stanu słuchu fonematycznego również u pacjentów dorosłych stworzyły Elżbieta Szeląg i Aneta Szymaszek [7]. Autorki te wyszły z założenia, że badając stan słuchu fonematycznego, należy uwzględnić elementy znaczeniowe, zatem lepiej wykorzystać w badaniu testy zdaniowe niż wyrazowe czy sylabowe, wykorzystywane w teście opracowanym przez Styczek. Samo narzędzie składa się z zestawu obrazków oraz zdań opisujących te obrazki nagranych na płycie CD.

\section{Program implantów pniowych w Polsce}

W 1998 roku prof. Henryk Skarżyński, we współpracy ze specjalistami z Niemiec i Austrii, rozpoczął w Polsce, w Instytucie Fizjologii i Patologii Słuchu, program implantów pniowych, przeprowadzając pierwszą operację wszczepienia implantu pniowego u pacjentki z NF2 [10]. Po dwóch latach rehabilitacji pacjentka uzyskała w testach dyskryminacji mowy wyniki potwierdzające możliwości rozumienia ze słuchu, bez posiłkowania się czytaniem $z$ ust [11]. Wynik ten uznano za ogromny sukces $\mathrm{z}$ uwagi na to, że większość dotychczas operowanych na świecie pacjentów - użytkowników systemu implantu pniowego nie uzyskiwała możliwości dyskryminacji mowy w testach otwartych bez posiłkowania się odczytywaniem mowy $z$ ust [12].

W 2008 roku w IFPS pacjentowi, który korzystał z implantu pniowego po stronie prawej, wszczepiono - po raz pierwszy na świecie - implant do pnia mózgu również po stronie lewej. Pacjent ten stał się pierwszym użytkownikiem dwóch implantów pniowych, tj. wszczepionych obustronnie. Pacjent aktywnie uczestniczył w dwuletnim procesie rehabilitacji słuchowej i uzyskał bardzo dobre wyniki w testach dyskryminacji mowy [2]. Uzasadnione stało się sprawdzenie, na jakim poziomie funkcjonuje jego słuch fonetyczny, to znaczy, w jakim stopniu pacjent faktycznie słyszy wszystkie głoski, a w jakim domyśla się, o które chodzi, na podstawie kontekstu zdania czy sytuacji. 

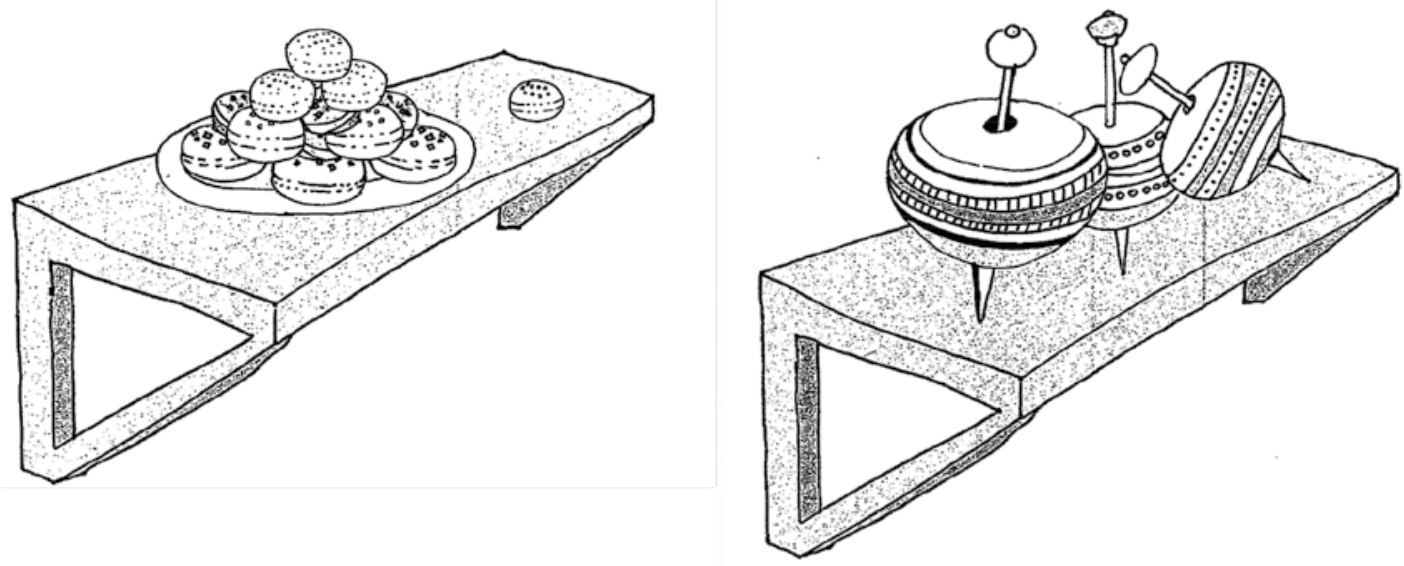

Rycina 1. Obrazki ilustrujące opozycję zdań: Na pótce leżą pączki i Na półce leżą bączki

Figure 1. Pictures showing the opposition of sentences: Donuts lie on the shelf and Spinning tops lie on the shelf

\section{Cel pracy}

Celem pracy jest ocena stanu słuchu fonematycznego u pacjenta z dwoma implantami pniowymi, w tym ocena możliwości dyskryminacji głosek opozycyjnych, co jest jednym z warunków umożliwiających prawidłowy odbiór mowy.

\section{Material i metody}

Ocenę stanu słuchu fonematycznego wykonano u 32-letniego mężczyzny, po 5 latach korzystania z dwóch systemów implantu pniowego.

Obustronne guzy kąta mostowo-móżdżkowego zostały po raz pierwszy zdiagnozowane w 2004 roku, objawem zgłaszanym przez pacjenta był niedosłuch oraz obustronne szumy uszne. W lutym 2006 r. wykonano kraniotomię $\mathrm{z}$ resekcją nerwiaka nerwu słuchowego po stronie prawej z jednoczesnym wszczepieniem implantu pniowego.

Po upływie 2 miesięcy od zabiegu pacjentowi podłączono w Zakładzie Implantów i Percepcji Słuchowej Instytutu Fizjologii i Patologii Słuchu procesor mowy, czyli zewnętrzną część implantu. W Klinice Rehabilitacji prowadzono rehabilitację słuchu, obejmująca przede wszystkim systematyczny trening słuchowy. W pierwszym etapie rehabilitacji treningi słuchowe opierają się na nauce wykrywania dźwięków, różnicowania ich oraz rozpoznawania. Drugi etap obejmuje naukę rozumienia mowy: najpierw w korzystnych warunkach, następnie na tle hałasu. $\mathrm{W}$ tym czasie pacjent korzystał $\mathrm{z}$ implantu pniowego po stronie prawej oraz $\mathrm{z}$ aparatu słuchowego po stronie lewej, gdzie występowały niewielkie resztki słuchowe.

W roku 2008 przeprowadzono operację usunięcia guza kąta mostowo-móżdżkowego po stronie lewej i dokonano jednoczasowego wszczepienia implantu pniowego po tej stronie. Od tego czasu pacjent korzysta $\mathrm{z}$ dwóch systemów implantu pniowego. Pacjent był również kilkakrotnie operowany z powodu licznych guzów w kręgosłupie.

Przeprowadzone - w warunkach obustronnej stymulacji elektrycznej realizowanej przez dwa systemu implantu pniowego - badanie słuchu fonematycznego miało na celu udzielić odpowiedzi na następujące pytania:
1. Ilu głosek nie różnicuje pacjent, kiedy korzysta wyłącznie ze słuchowej drogi odbioru?

2. Które głoski sprawiają mu problemy?

3. Czy u pacjenta występuje deficyt słuchu fonematycznego? Jeśli tak, to na jakim poziomie?

Badanie słuchu fonematycznego przeprowadzono za pomocą testu autorstwa Szeląg i Szymaszek. Test składa się ze 106 zdań i ilustrujących je obrazków. Pierwsze 10 zdań to przykłady służące wprowadzeniu do badania właściwego, na które składa się 96 pozostałych zdań. Zdania te zawierają pary słów różniące się jednym fonemem. Autorki ułożyły z nich 4 listy: 1 . i 2 . zawierają po 54 zdania ułożone w kolejności losowej, natomiast na listach 3. i 4. uporządkowano je według opozycji spółgłoskowych - te listy można wykorzystać w celu sprawdzenia stanu różnicowania kolejno poszczególnych opozycji spółgłoskowych. W trakcie badania wykorzystano listy 1 . i 2 . zgodnie z zaleceniami autorek. Sześć pierwszych zdań na każdej liście służy do wprowadzenia osoby badanej do badania właściwego. Zdania zostały nagrane na płycie CD, którą należy odtworzyć w trakcie badania. Odpowiedzi badanego można zaznaczać na karcie odpowiedzi.

Zadaniem osoby badanej jest wysłuchanie zdania i wskazanie obrazka ilustrującego jego treść. Warunkiem koniecznym do przeprowadzenia badania właściwego jest poprawne wskazanie przez osobę badaną czterech pierwszych przykładowych obrazków.

W przypadku błędnej odpowiedzi możliwe jest ewentualne powtórzenie zdania, ale tylko jednego. Następnie prezentowane są pozostałe dwa zdania z grupy przykładów. Tu, $\mathrm{w}$ razie błędu, możliwe jest powtórzenie zdań z naciskiem na słowa kluczowe. W przypadku poprawnego zidentyfikowania wyrazów można przejść do badania właściwego. $\mathrm{Na}$ tym etapie badany słucha serii nagrań, a przed nim prezentowane są pojedynczo karty odpowiedzi zawierające po dwa obrazki. Badany po wysłuchaniu zdania wskazuje właściwy - w jego ocenie - obrazek, odpowiadający słyszanej informacji. Następnie prezentowane jest kolejne zdanie i kolejne obrazki. Osoba badana otrzymuje informację zwrotną dopiero po wykonaniu badania. 
Tabela 1. Zestaw zdań zilustrowanych na kartach odpowiedzi (lista 1 i lista 2). Zdania wprowadzające wyróżniono kursywą. Słowa kluczowe w zdaniach właściwych wyróżniono pogrubionym drukiem. Ostatnie trzy kolumny w każdej liście stanowią klucz, ułatwiający przyporządkowanie danego słowa kluczowego w zdaniu do odpowiedniej opozycji spółgłoskowej. Objaśnienia do klucza: • paronimy różniące się dźwięcznością; $\mathbf{a}$ paronimy różniące się miejscem artykulacji

Table 1. Set of sentences illustrated on reply cards (list 1 and list 2). Topic sentences are in italics. Keywords in appropriate sentences are in bold. Three last units in every list constitute the key, facilitating assigning a given keyword to the right consonantal opposition. Of explaining up to the key: $\bullet$ paronyms differing in the sonorousness; $\mathbf{a}$ paronyms differing in the place of the articulation

\begin{tabular}{|c|c|c|c|c|c|}
\hline \multicolumn{6}{|c|}{ LISTA 1} \\
\hline \multirow{3}{*}{ Lp. } & \multirow{3}{*}{ Zdanie } & \multirow{3}{*}{$\begin{array}{l}\text { Poprawność } \\
\text { odpowiedzi }\end{array}$} & \multicolumn{3}{|c|}{ Klucz } \\
\hline & & & \multicolumn{3}{|c|}{ Opozycje spółgłosek } \\
\hline & & & Zwartych & Szczelinowych & $\begin{array}{l}\text { Zwarto- } \\
\text { otwartych }\end{array}$ \\
\hline 1. & Samochód jedzie do kościota. & & & & \\
\hline 2. & Krzesło stoi na podłodze. & & & & \\
\hline 3. & Bawię się pitką. & & & & \\
\hline 4. & Bawię się z kotem. & & & & \\
\hline 5. & Na podwórku jest dużo kości. & & $\bullet$ & & \\
\hline 6. & Na podwórku jest dużo gości. & & $\bullet$ & & \\
\hline 7. & Dziecko trzyma paczuszkę/kaczuszkę. & & $\mathbf{\square}$ & & \\
\hline 8. & Za płotem stoi domek/Tomek. & & $\bullet$ & & \\
\hline 9. & Na plaży stoi nurek/murek. & & & & $\mathbf{\square}$ \\
\hline 10. & Mężczyzna fotografuje korzenie/koszenie. & & & $\bullet$ & \\
\hline 11. & Na półce leżą bączki/pączki. & & $\bullet$ & & \\
\hline 12. & W barze/garze są dobre pierogi. & & $\mathbf{\square}$ & & \\
\hline 13. & Chłopiec dostał taczkę/paczkę. & & $\mathbf{\square}$ & & \\
\hline 14. & Dziecko trzyma kaczuszkę/paczuszkę. & & - & & \\
\hline 15. & To jest zniszczony wrak/frak. & & & $\bullet$ & \\
\hline 16. & To jest szok/sok. & & & - & \\
\hline 17. & W łazience stoi wanna/Hanna. & & & $\bullet$ & \\
\hline 18. & Do sklepu przywieziono bułki/półki. & & $\bullet$ & & \\
\hline 19. & Dziewczynka obserwuje krę/grę. & & $\bullet$ & & \\
\hline 20. & Za płotem stoi Tomek/domek. & & $\bullet$ & & \\
\hline 21. & To jest wysoka fala/sala. & & & घ & \\
\hline 22. & Pod liśćmi siedzą liski/kiszki. & & & घ & \\
\hline 23. & Kobieta pokazuje nowe szale/sale. & & & - & \\
\hline 24. & Chłopiec dostał paczkę/kaczkę. & & $\mathbf{\square}$ & & \\
\hline 25. & Z daleka widać loty/lody. & & $\bullet$ & & \\
\hline 26. & On niesie nartę/Martę. & & & & घ \\
\hline 27. & W garze/barze są dobre pierogi. & & - & & \\
\hline 28. & Kobieta pokazuje nowe sale/szale. & & & - & \\
\hline 29. & Do sklepu przywieziono półki/bułki. & & $\bullet$ & & \\
\hline 30. & Na półce leżą pączki/bączki. & & $\bullet$ & & \\
\hline
\end{tabular}




\begin{tabular}{|c|c|c|c|c|c|}
\hline 31. & Na plaży stoi murek/nurek. & & & & $\mathbf{\square}$ \\
\hline 32. & W łazience jest tran/kran. & & $\mathbf{\square}$ & & \\
\hline 33. & Na podwórku stoi kurnik/górnik. & & $\bullet$ & & \\
\hline 34. & Pod drzewem jest gruszka/dróżka. & & $\mathbf{\square}$ & & \\
\hline 35. & To jest wysoka sala/fala. & & & $\boldsymbol{\square}$ & \\
\hline 36. & Ten wąż/wąs jest czarny. & & & $\mathbf{\square}$ & \\
\hline 37. & Chłopiec liczy balie/dalie. & & $\mathbf{\square}$ & & \\
\hline 38. & Ten wąs/wąż jest czarny. & & & $\mathbf{\square}$ & \\
\hline 39. & Z daleka widać lody/loty. & & $\bullet$ & & \\
\hline 40. & Dziewczynka obserwuje grę/krę. & & $\bullet$ & & \\
\hline 41. & Chłopiec liczy dalie/balie. & & $\mathbf{\square}$ & & \\
\hline 42. & To jest sok/szok. & & & $\mathbf{\square}$ & \\
\hline 43. & To jest zniszczony frak/wrak. & & & $\bullet$ & \\
\hline 44. & Na podwórku stoi kosa/koza. & & & $\bullet$ & \\
\hline 45. & Mężczyzna fotografuje koszenie/korzenie. & & & $\bullet$ & \\
\hline 46. & W łazience jest kran/tran. & & $\mathbf{\square}$ & & \\
\hline 47. & Po drzewem jest dróżka/gruszka. & & $\mathbf{\square}$ & & \\
\hline 48. & Na podwórku stoi koza/kosa. & & & $\bullet$ & \\
\hline 49. & Na podwórku stoi górnik/kurnik. & & $\bullet$ & & \\
\hline 50. & W lesie jest szałas/hałas. & & & $\mathbf{\square}$ & \\
\hline 51. & Po liśćmi siedzą liszki/kiszki. & & & - & \\
\hline 52. & On niesie Martę/nartę. & & & & $\mathbf{\square}$ \\
\hline 53. & W łazience stoi Hanna/wanna. & & & $\bullet$ & \\
\hline 54. & W lesie jest hałas/szałas. & & & $\mathbf{\square}$ & \\
\hline \multicolumn{6}{|c|}{ LISTA 2} \\
\hline \multirow{3}{*}{ Lp. } & \multirow{3}{*}{ Zdanie } & \multirow{3}{*}{$\begin{array}{l}\text { Poprawność } \\
\text { odpowiedzi }\end{array}$} & \multicolumn{3}{|c|}{ Klucz } \\
\hline & & & \multicolumn{3}{|c|}{ Opozycje spółgłosek } \\
\hline & & & Zwartych & Szczelinowych & $\begin{array}{l}\text { Zwarto- } \\
\text { otwartych }\end{array}$ \\
\hline 1. & Krzesto stoi na stole. & & & & \\
\hline 2. & Bawię się z bratem. & & & & \\
\hline 3. & Samochód jedzie nad jezioro. & & & & \\
\hline 4. & Bawię się pitką. & & & & \\
\hline 5. & Na podwórku jest dużo kości. & & $\bullet$ & & \\
\hline 6. & Na podwórku jest dużo gości. & & $\bullet$ & & \\
\hline 7. & Lekarze gadają/badają w pokoju. & & $\mathbf{\square}$ & & \\
\hline 8. & W sklepie jest kasa/kasza. & & & घ & \\
\hline 9. & Samochód przywiózł kraty/graty. & & $\bullet$ & & \\
\hline 10. & Na gałęzi są bąki/pąki. & & $\bullet$ & & \\
\hline 11. & Na podłodze leży korba/torba. & & $\mathbf{\square}$ & & \\
\hline
\end{tabular}




\begin{tabular}{|c|c|c|c|}
\hline 12. & Na podwórku stoją buty/budy. & $\bullet$ & \\
\hline 13. & Chłopiec układa tory/pory. & $\bullet$ & \\
\hline 14. & Dziecko ma kaszel/kafel. & & $\mathbf{\square}$ \\
\hline 15. & Na podłodze leży torba/korba. & $\mathbf{\square}$ & \\
\hline 16. & Aktor ma piękny pas/bas. & $\bullet$ & \\
\hline 17. & Z rzeki wydobywa się sum/szum. & & - \\
\hline 18. & Pod drzewem jest kos/kosz. & & $\mathbf{\square}$ \\
\hline 19. & Chłopiec pokazuje nóżkę/muszkę. & $\mathbf{\square}$ & \\
\hline 20. & Za miastem jest zakon/zgon. & $\bullet$ & \\
\hline 21. & Mężczyzna ogląda port/kort. & & $\square$ \\
\hline 22. & Dziewczynka ogląda hotel/fotel. & & - \\
\hline 23. & To jest tama/dama. & $\bullet$ & \\
\hline 24. & Lekarze badają/gadają w pokoju. & $\mathbf{\square}$ & \\
\hline 25. & Mocny/Nocny strażnik pilnuje sklepu. & & \\
\hline 26. & Student czyta o żebrach/zebrach. & & $\mathbf{\square}$ \\
\hline 27. & Chłopiec układa pory/tory. & $\mathbf{\square}$ & \\
\hline 28. & Ona pokazuje dar/bar. & $\mathbf{\square}$ & \\
\hline 29. & Na podwórku stoją budy/buty. & $\bullet$ & \\
\hline 30. & Mężczyźni reperują nosze/noże. & & $\mathbf{\square}$ \\
\hline 31. & To jest dama/tama. & - & \\
\hline 32. & Dziewczynka ogląda fotel/hotel. & & $\mathbf{\square}$ \\
\hline 33. & Na gałęzi są pąki/bąki. & - & \\
\hline 34. & Chłopiec pokazuje muszkę/nóżkę. & & \\
\hline 35. & W sklepie jest kasza/kasa. & & $\mathbf{\square}$ \\
\hline 36. & Nocny/Mocny strażnik pilnuje sklepu. & & \\
\hline 37. & Samochód przywiózł graty/kraty. & $\bullet$ & \\
\hline 38. & Z rzeki wydobywa się szum/sum. & & - \\
\hline 39. & Student czyta o zebrach/żebrach. & & - \\
\hline 40. & Pod drzewem jest kosz/kos. & & $\mathbf{\square}$ \\
\hline 41. & Kobieta niesie gary/dary. & $\mathbf{\square}$ & \\
\hline 42. & Kobieta długo szyje/żyje. & & ○ \\
\hline 43. & Dziecko ma kafel/kaszel. & & - \\
\hline 44. & Mężczyzna ogląda kort/port. & $\mathbf{\square}$ & \\
\hline 45. & Mężczyźni reperują noże/nosze. & & $\bullet$ \\
\hline 46. & Kobieta długo żyje/szyje. & & $\bullet$ \\
\hline 47. & Kobieta choruje/szoruje. & & - \\
\hline 48. & Kobieta niesie dary/gary. & $\mathbf{\square}$ & \\
\hline 49. & On pokazuje bar/dar. & $\mathbf{\square}$ & \\
\hline 50. & Dziewczynka narysowała chustkę/szóstkę. & & $\mathbf{\square}$ \\
\hline
\end{tabular}




\begin{tabular}{clc}
\hline \hline & & $\bullet$ \\
\hline 51. & Za miastem jest zagon/zakon. & \\
\hline 52. & Dziewczynka narysowała szóstkę/chustkę. & $\mathbf{0}$ \\
\hline 53. & Kobieta szoruje/choruje. & $\bullet$ \\
\hline 54. & Aktor ma piękny bas/pas. & $\mathbf{0}$ \\
\hline
\end{tabular}

Tabela 2. Uzyskane wyniki badania

Table 2. Results of the examination

\begin{tabular}{|c|c|c|}
\hline & Próba pierwsza & Próba druga \\
\hline Liczba opozycji nierozróżnianych & 7 & 4 \\
\hline Typ opozycji nierozróżnianych & Błędy związane z miejscem artykulacji & Błędy związane z miejscem artykulacji \\
\hline $\begin{array}{l}\text { Liczba nierozróżnianych członów danej } \\
\text { opozycji }\end{array}$ & $\begin{array}{c}6 \\
b-g \\
b-d \\
k-t \\
m-n \\
p-t \\
s-s z\end{array}$ & $\begin{array}{c}3 \\
m-n \\
p-t \\
b-d\end{array}$ \\
\hline
\end{tabular}

Przeprowadzono dwie próby w ciszy w warunkach odsłuchowych: 1) przez słuchawki założone tak, aby mikrofony procesorów mowy były nimi objęte oraz 2) przez głośniki. Informację zwrotną dotyczącą poprawności odpowiedzi badany otrzymał dopiero po wykonaniu obu prób.

\section{Wyniki}

W próbie pierwszej (badanie w słuchawkach) badany popełnił dziesięć błędów: sześć w zdaniach z listy 1. i cztery w zdaniach z listy 2 . Wszystkie błędy dotyczyły paronimów różniących się miejscem artykulacji. Badany nie pomylił się ani razu, kiedy chodziło o paronimy różniące się dźwięcznością.

Trzy błędy z listy 1. dotyczyły opozycji spółgłosek zwartych [t-p] [t-k], dwa spółgłosek zwarto-otwartych [m-n] i jeden spółgłosek szczelinowych [s-sz].

Błędy z listy 2. dwa razy dotyczyły opozycji spółgłosek zwartych [b-g] [b-d] i dwa razy spółgłosek zwarto-otwartych $[\mathrm{m}-\mathrm{n}]$.

W próbie drugiej (bez słuchawek) badany popełnił siedem błędów: cztery w zdaniach z listy 1 . i trzy w zdaniach z listy 2 . Tym razem pomyłki również dotyczyły różnic związanych z miejscem artykulacji głosek opozycyjnych. Trzy błędy z listy 1. dotyczyły opozycji spółgłosek zwarto-otwartych [m-n] i jeden spółgłosek zwartych [t-p]. W badaniu za pomocą listy 2 . dwa błędy dotyczyły spółgłosek zwarto-otwartych [m-n] i jeden spółgłosek zwartych [d-b].

Mniejszą liczbę błędów w próbie 2. sam badany wyjaśnił lepszym odbiorem dźwięku z głośników. Zebrane wyniki badanego przedstawia tabela 2 .

Przeprowadzony test wykazał, że pacjent nie ma większych problemów z komunikacją: nie ma on trudności $\mathrm{z}$ rozumieniem mowy w sprzyjających warunkach akustycznych. Ponieważ badanie przeprowadzone było z użyciem nagrania z płyty $C D$, pacjent odpowiadał jedynie na podstawie tego, co usłyszał przez procesory implantów.

Badany miał problemy z rozróżnianiem kilku głosek opozycyjnych z kategorii miejsca artykulacji. Błędy dotyczyły przede wszystkim głosek zwartych i nosowych. Dodatkowo warto zaznaczyć, że w porównaniu z Próbą 1. powtórzyły się błędy dotyczące tylko trzech opozycji, które uznać można za problematyczne dla badanego.

Wyniki przeliczono na procenty: w pierwszej próbie pacjent rozpoznał prawidłowo $90 \%$ materiału testowego, w drugiej 95\%.

\section{Dyskusja}

Proces odbioru i rozumienia dźwięków jest czynnością złożoną, zależną od wielu czynników. Przede wszystkim należy uwzględnić dwa typy uzupełniających się procesów poznawczych. Pierwszy z nich - przetwarzanie oddolne nazywany procesem „dół-góra” dotyczy możliwości odbioru dźwięku przez receptor słuchowy i przekazania go do wyższych pięter drogi słuchowej, gdzie dochodzi do wstępnej analizy. Tutaj niezwykle istotna jest dokładność przekazu związana $\mathrm{z}$ podstawowymi funkcjami percepcyjnymi, takimi jak: głośność, barwa i wysokość dźwięku [13]. Drugi przetwarzanie odgórne - nazywany procesem „góra-dół” dotyczy interpretacji odebranego sygnału na podstawie wcześniejszych doświadczeń czy wiedzy i ewentualną interakcję $\mathrm{z}$ otoczeniem na podstawie uzyskanej informacji. Skuteczna komunikacja jest uzależniona od funkcjonowania trzech elementów związanych z przetwarzaniem odgórnym: prędkości przetwarzania dźwięków, umiejętności wykorzystywania kontekstu sytuacyjnego i zdaniowego oraz pojemności pamięci operacyjnej. Czynniki te mają szczególnie duże znaczenie, kiedy odbierane informacje akustyczne są zbyt ubogie lub niepełne, np. w warunkach hałasu [13].

Omawiany pacjent wykazuje umiejętności rozumienia mowy na drodze słuchowej, co potwierdzono badaniami [2]. 
Na jakość uzyskanego za pomocą implantu pniowego słuchu składa się kilka elementów: czynniki medyczne, czynniki dotyczące implantu oraz czynniki osobnicze. Jak wykazały badania [14], na dokładność przekazu informacji o dźwięku u pacjentów z implantem pniowym wpływają czynniki takie jak: technika usuwania zmian nowotworowych przez chirurga, ułożenie matrycy elektrod implantu w obszarze jąder ślimakowych w pniu mózgu, poziomy stymulacji, częstotliwość stosowanych impulsów stymulujących oraz czas trwania niedosłuchu. Pacjent przed zdiagnozowaniem NF2 zajmował się zawodowo muzyką. Jego kora mózgowa, odpowiadająca za przetwarzanie informacji akustycznych, była zatem długotrwale i intensywnie pobudzana. Pośrednio przyczyniło się to do wytworzenia się dużej ilości połączeń między neuronami, a to z kolei pozwoliło na skuteczne przetwarzanie dźwięków po implantacji. Niedostateczna ilość bodźców akustycznych, spowodowana niedosłuchem, prowadzi do stopniowej utraty umiejętności analizy tych informacji przez korę. Zatem krótki czas przebywania w ciszy również zadziałał na korzyść pacjenta.

Przeprowadzone badanie wykluczało udział elementów pomocniczych związanych z przetwarzaniem bodźców dźwiękowych, takich jak korzystanie z kontekstu czy wspomaganie się ruchem warg. Skoncentrowano się głównie na zdolności dyskryminacji opozycji fonetycznych, polegając tylko na odebranym sygnale akustycznym. Uzyskane przez pacjenta wyniki wskazują na sprawne działanie procesów „dół-góra” i pozwalają na wnioskowanie, że sygnał przesyłany przez implant jest na tyle kompletny, że pacjent jest w stanie dyskryminować podobnie brzmiące słowa na podstawie ich brzmienia. Z kolei wcześniejsze badania [10] dyskryminacji mowy u pacjenta wskazały na sprawne działanie procesów „góra-dół”, co pozwala mu na poprawne odbieranie i przetwarzanie bodźców słuchowych w trakcie rozmowy, zarówno w ciszy (70\% rozpoznawanych słów jednosylabowych), jak i w hałasie (50\% słów jednosylabowych).
Czynniki osobnicze pacjenta oraz podjęta interwencja medyczna, w tym praca specjalistycznego zespołu inżynierów i rehabilitantów, bez wątpienia przyczyniły się do uzyskiwania przez pacjenta wysokich wyników w testach dyskryminacji mowy.

\section{Wnioski}

Implant pniowy pozwala pacjentowi - w sprzyjających akustycznie warunkach - na odbiór i różnicowanie opozycyjnych głosek oraz paronimów bez posiłkowania się kontekstem wypowiedzi. Wszczepienie implantu pniowego jest zatem skuteczną metodą kompensowania utraconego słuchu w przebiegu neurofibromatozy typu 2. Przeprowadzone badanie wykazało, że sygnał przekazywany do mózgu przez implant pniowy jest w stanie oddać prawie wszystkie właściwości głoski. Obecnie brak doniesień na temat wyników badań dotyczących słuchu fonematycznego u innych użytkowników ABI. Przeprowadzane do tej pory badania, za pomocą testów słów jednosylabowych czy testów zdaniowych, pozwalają na ocenę, czy badany rozpoznaje i jest w stanie powtórzyć słowa czy też całe zdania wypowiadane w ciszy lub w hałasie. Wskazane byłoby przeprowadzanie badań słuchu fonematycznego u innych użytkowników implantów pniowych, w sposób umożliwiający porównywanie wyników, co pozwoliłoby na zdefiniowanie czynników i/lub parametrów warunkujących możliwości rozumienia mowy w tej grupie pacjentów. Ważne jest, aby kryterium rozumienia mowy było rozpoznawanie na drodze słuchowej składowych słów i zdań. Należałoby również sprawdzić, na ile pomocny i skuteczny w poprawie dyskryminacji mowy jest trening słuchowy u pacjentów z ABI. Przeprowadzenie testu słuchu fonematycznego przed treningiem słuchowym i po takim treningu umożliwiłoby ocenę skuteczności podjętej interwencji.

\section{Piśmiennictwo:}

1. Shannon RV. Auditory Brainstem Implants. The Asha Leader; 2011.

2. Mendel T, Wierzba-Bobrowicz T, Skarżyński H, Stępień T, Członkowska A. Nerwiakowłókniakowatość typu 2: opis przypadku. Postępy Psychiatrii i Neurologii, 2013; 22(2): 149-55.

3. Kania S. Szkice logopedyczne. Warszawa: WSiP; 1982.

4. Styczek I. Badanie i kształtowanie słuchu fonemowego. Tablice i komentarz. Warszawa: WSiP; 1982.

5. Rocławski B. Słuch fonemowy i fonetyczny. Teoria i praktyka. Gdańsk: GLOTTISPOL; 1995.

6. Domagała A, Mirecka U. Słuch fonemowy. W kierunku kompetencji fonologicznej. Logopedia, 2002, 30: 7-26.

7. Szeląg E, Szymaszek A. Test do badania słuchu fonematycznego u dzieci i osób dorosłych. Gdańsk: GWP; 2006.

8. Urbańczyk S. Encyklopedia wiedzy o języku polskim. Wrocław; 1978, s. 82.

9. Kurkowski ZM. Audiogenne uwarunkowania zaburzeń mowy. Audiofonologia, 1997; 10: 103-9.
10. Skarżyński H, Behr R, Lorens A, Podskarbi-Fayette R, Kochanek K. Bilateral electric stimulation from auditory breinstem implants in a patient with neurofibromatosis type 2. Med Sci Monit, 2009; 15(6): 100-4.

11. Skarżyński H, Szuchnik J, Lorens A, Zawadzki R, Miszka K, Śliwa L i wsp. Wyniki słuchowe w implancie pniowym po 2 latach rehabilitacji w trzech językach Audiofonologia, 2000; 18: 31-35.

12. Colletti V, Shannon RV. Open set speech perception with auditory brainstem implant? The Larngoscope, 2005; 115, 1974-78.

13. Kramer S, Zekveld A, Houtgast T. Measuring cognitive factors in speech comprehension: The value of using the Text Reception Threshold test as a visual equivalent of the SRT test. Scand J Psychol, 2009; 50: 507-15.

14. Behr R, Colletti V, Cordula M, Morita A, Nakatomi H, Dominique L i wsp. New outcomes with auditory brainstem implants in NF2 patients. Otol Neurol, 2014, 35: 1844-51. 